\title{
Linking Citizenship to Income Undermines European Values. We Need Shared Criteria and Guidelines for Access to EU Citizenship
}

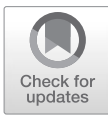

\author{
Hannes Swoboda
}

The decision by the Maltese Parliament to offer Maltese citizenship - and consequently - EU citizenship to third country nationals who can afford to pay $€ 650.000$ comes as a closure of the EU year of citizens and reflects a worrying trend in the conception of all those rights related to EU citizenship, including above all freedom of movement.

Malta is not an isolated case, though. As highlighted by other contributions to this Forum, other EU Member States have in time come to link access to residence and hence - albeit indirectly - to citizenship to income or to economic investment, although the Maltese proposal goes a step further by introducing a direct and free gateway to citizenship purely based on a monetary payment.

Some may say that access to nationality is an exclusive competence of Member States and that the European Union has no right to interfere in these choices. From a purely legal perspective I would agree, but I believe we would miss the point if we did not see that, behind monetization of citizenship and residence, there is a vital political issue for the European Union to face, if we believe that Europe is more than just a wide single market.

The political debate about the so-called 'poverty migration' in the EU and on limitations to free movement for Romanian and Bulgarian citizens is just another side of the same coin. The supporters of the idea that 'free movement has to be less free' base their belief on the assumption that free movement should be free for those citizens who have a suitable income and less free for those who have not.

This questions the idea of citizenship as the core of a society, as the set of rights and duties defining active participation in the political, social and economic life of a community on an equal basis. And it questions the very idea of a European citizenship as a set of special rights connected to being a member of the European Union as a political Union, where individuals, notwithstanding their income and social position, can on an equal footing 
organise, participate in decisions in a wider European public space and feel part of a common project because that project is a collective benefit for all.

I would say that the very idea of the European Union as a community of values is put in question by these trends, particularly the idea that it is the duty of the EU to reinforce social cohesion, to eliminate discriminations and to provide a level playing field for the material exercise of the fundamental rights defined in the EU Charter.

I have often expressed the idea, including in the framework of EUDO debates, that access to EU citizenship needs to be expanded and not limited further, if we believe in making progress in the conception of a political and social Union.

I have often mentioned, for example, that many 'new Europeans' already live, study, work in our societies and contribute to them - some have been born and raised in Europe - but still are limited in their access to citizenship. These fellow Europeans have to go through detailed and lengthy citizenship tests before they can hope to achieve naturalisation in a Member State and therefore be fully EU citizens. I am convinced that - should Member States go in the direction of a privileged gateway to national citizenship solely based on income - this would create an unacceptable discriminatory situation that is probably also incompatible with EU law as it currently stands.

This is why I believe that a serious reflection at EU level is necessary ahead of European elections this year - also taking stock of the debates that characterised 2013 as the Year of EU citizens - on which common and shared criteria and guidelines should guide access to national citizenship and hence to EU citizenship at national level.

I think this is a necessary and urgent discussion we need to face. The background for the trend in citizenship policies that we are currently witnessing is of course more complex and it has to do with the on-going erosion of trust in institutions and with the fact that more and more among those who possess citizenship of the Union feel that they are not yet (or not fully) citizens, both at national and European level.

The real challenge is how European citizenship can be relaunched in a bottom-up process where EU citizens can enter the stage of the EU political arena, campaign for policy options, actively debate in a truly European public space and select legislators representing their views and working for their objectives. 
If we don't want to leave a golden opportunity to Eurosceptics, nationalists and populists, we must seize the chance for a leap forward in the European process involving a much wider concept of citizenship than that defined in the letter of the EU Treaties.

Open Access This chapter is licensed under the terms of the Creative Commons Attribution 4.0 International License (http://creativecommons.org/licenses/by/4.0/), which permits use, sharing, adaptation, distribution and reproduction in any medium or format, as long as you give appropriate credit to the original author(s) and the source, provide a link to the Creative Commons license and indicate if changes were made.

The images or other third party material in this chapter are included in the chapter's Creative Commons license, unless indicated otherwise in a credit line to the material. If material is not included in the chapter's Creative Commons license and your intended use is not permitted by statutory regulation or exceeds the permitted use, you will need to obtain permission directly from the copyright holder.

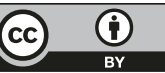

